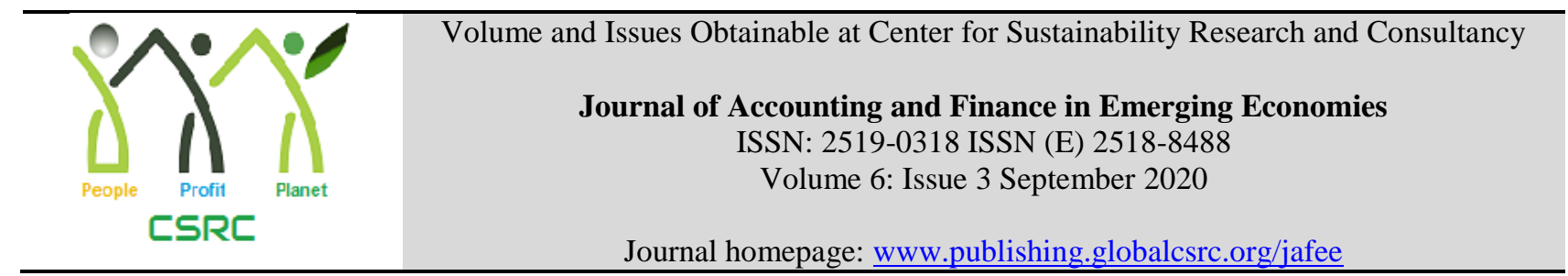

\title{
Monetary Policy Channels and Industrial Production in Pakistan: Evidences based on ARDL Approach
}

\author{
${ }^{1}$ Muhammad Tariq Mahmood, ${ }^{2}$ Sadaf Shahab, ${ }^{3}$ Saad Ali Rabbani \\ ${ }^{1 \& 2}$ Assistant Professor, Department of Economics, Federal Urdu University of AS \& T, Islamabad, Pakistan, \\ tm76pk@gmail.com \\ ${ }^{3}$ MPhil Scholar, Department of Economics, Federal Urdu University of AS \& T, Islamabad, Pakistan
}

\begin{tabular}{l}
\hline ARTICLE DETAILS \\
\hline History \\
Revised format: August 2020 \\
Available Online: September \\
2020
\end{tabular}

\section{Keywords}

Monetary policy, Industrial

production, ARDL,

expansionary,

JEL Classification

M40,M41

\section{ABSTRACT}

Monetary policy is a significant component of economic management, with which we can control higher inflation, boost the economic growth and stabilize the other macroeconomic activities. This study investigates the channels of monetary policy affecting the industrial production using monthly data of Pakistan. In this regard, we have applied Bound test for co-integration to investigate the dynamic behaviour of the variables. Our results indicate that the consumer prices, money supply and money market rates are negatively effective for industrial production in the short-run. On the other hand, exchange rate has positive effect in short-run. The results also indicate that there is statistically significant and positive relationship between industrial output and money supply in the long-run, too. The adjustment mechanism suggests stability in the system and is statistically significant. Our results imply that the authorities should use expansionary monetary stance through money supply channel to boost the industrial sector.

\section{OPEN ACCESS}

(C) 2020 The authors, under a Creative Commons Attribution-NonCommercial 4.0

Corresponding author's email address: tm76pk@ gmail.com

Recommended citation: Mahmood, M, T., Shahab, S., \& Rabbani, S, A. (2020). Monetary Policy Channels and Industrial Production in Pakistan: Evidences based on ARDL Approach. Journal of Accounting and Finance in Emerging Economies, 6(3), 713-721

\section{Introduction}

The main goal of monetary policy is to achieve the sustainable economic growth and to determine the role of other socioeconomic activities in the country. In modern economics, the supervision of money market, regulation of money supply and the management of banking system are merged in a phrase "Monetary Policy". The policy makers use monetary policy as a tool to control the financial sector of the economy. Furthermore, the monetary policy is influential for credit channels, balance of trade, money supply channels, interest rate channels and unemployment rate. The correct diagnosis of monetary policy channels is very important for any given economy. The previous literature investigated the relationship between monetary policy channels in detail but the part of the industrial sectors has less unexplored in the case of Pakistan. The industrial sectors are main and key role in developed and developing countries. The economists used various econometric methods to investigate the relationships between the monetary policy channels and industrial growth. The most practical method is Autoregressive Distributed Lag (ARDL) approach. Many economists investigated the short run and long run associations among the monetary policy channels through distributed lag model (ARDL). Among these renowned, Banerjee et al. (1993), investigated the ARDL model 
through simple linear equation and found the dynamic of short run relationship with the help of Error Correction Model (ECM). The ECM is the measurement of the short run behaviour with long run equilibrium without losing long run sequence.

The key link between monetary channels and economy needs to be paid attention at in recent economy due to the financial crises. In this principle, we analyze the dynamics relationships of variables, such as Industrial Manufacture Product Index (Y), Money Supply (M2), Money Market Rate (MMR), Nominal Effective Exchange Rate (NEER) and Consumer Price Index (CPI), our model is similar to Dingela and Khobai (2017). Although the Dingela and Khobai (2017) model is not designed for Pakistan economy, but they analyzed the mechanism of macroeconomic variables with the help of ARDL approach.

In addition, there are a number of reasons, why we might be choosing ARDL model to estimate the relationship between monetary policy channels and industrial sector growth in Pakistan. Firstly, the ARDL model are being used broadly on the data of developing and developed countries to analyse the economic growth. For example, Rabi and Waliullah (2011) reveal strong evidence about the relationships between money supply, level of prices and Economic Growth (GDP). The monetary policy tools such as money supply has a stable and long run relationship with consumer price index (Rabi and Waliullah, 2011). Secondly, the ARDL model is simple and can correctly identify the time series analysis. Finally, we chose the ARDL model, it is useful to clearly understand the long run and short run behaviour of monetary channels and that is more critical for modern economy. The objective of this study is to find out the relationship between monetary policy instruments and the industrial production. Most of the earlier literature has done primarily focussed on the GDP, but we in this study have emphasized on the use of industrial production as proxy for output due to number of reasons; including the frequency of the series, and the suppose link between the investment and interest rate (theoretically). In this scenario, we analyzed our regression equations with ARDL approach.

The study has been divided into five sections. Section 1 introduces this study; section 2 is based on the review of existing literature; in section 3, we discussed model, methodology and description of variables; section 4 presents the empirical analysis. Section 5 concludes. References are given in the end.

\section{Literature Review}

The monetary policy plays a vital role in both open and closed economy. The following literature explains the monetary policy system by using Vector Autoregressive (VAR) and ARDL model, to examine the macroeconomic volatility in economy.

Bernanke and Mihov (1998) analyzed how change in monetary policy (interest rates) and their macroeconomic impact could be calculated via VAR models. Precise monetary policy measurement is important for the economy. Their method was semi-structural VAR, focused on reserve market measures, to estimate monetary policy. The paper's main conclusion is that, especially for the whole period 1965-1967 (for US) no clear determinants are available for reserve bank. Finally, the strutural-VAR model was proposed as an useful measure for monetary shocks.

The Structural Factor model was used as an experiment to detect the complex behaviour of monetary policy impacts by Forni and Gambetti (2008). Therefore, the two models Structural Factor and Structural Autoregressive Vector were compared. The Structural Factor Model allows us to use a large data set and avoid significant restrictions on VAR Structural models. With the help of the structural factor model, Forni and Ganbetti (2008) found that the real two-way exchange rates simultaneously respond to a tight monetary policy with a valuable appreciation and monetary policy shocks influence all forms of real and nominal variables considerably. Moreover, a contractionary monetary policy helps in the removing of price puzzle.

Qayyum (2008) examined the financial policy and its impacts to controlling the inflationary pressure in Pakistan. His finding suggest that high inflation rate should be control by authority because it adverse impact on overall commodity prices. The high and harmful inflation rate has inimical for the economic growth, developing and poor societies (people have limited assets). Aleem (2010) investigated the Transmission Mechanism of monetary policy in India and Pakistan by using financial channel approach. Its results indicate that the inclusion of exogenous variables in the 
model to improve the problem of price puzzle and checked the importance of each channel simultaneously by comparing two different impulse response shocks of GDP for the addition in the interest rate. The Bank lending channel is important for Indian economy, and the exchange rate channel is important for Pakistan (Aleem, 2010). On the other hand, Stevanovi (2010) found that the behaviour of economic factors has strong coordination with economic environments as these factors change over time. There are few structural relations that may vary over time which cause a time variation in parameters. The time variation has an important role in estimated coefficients of VAR model. Mahmood and Shahab (2012) explored the optimal shocks of monetary policy and its impacts on social welfare, considering a small open economy. When the central bank adopts discretion monetary policy for improvement in economy, the economy faces price puzzle and exchange rate puzzle which can damage in macroeconomic conditions. They discussed how the discretionary policies are not instantly effective in society as anticipated and that they are not appropriate for the welfare and exchange rate stream. With inflation, growth, and interest rates increasing, the liberal target is better than the tight target. We indicated that monetary policy based on the rule shows good results in production, output, consumption, and the open economy.

The co-integration and VECM techniques by Mustafa et al (2013) were used to test the connection between reserve prices and money supply in Pakistan. Results show that the financial supply and stock prices have a casual relation. They showed that the stock price had a negative, relevant and short-term casual impact on the supply of money. Further, Hanif (2014) addressed Pakistan's monetary environment mainly concerned with bank loan availability for control of its economic activity. For monetary related factors like bank loan, stock of money that causes economic impact, the SBP is responsible. Cooperation between fiscal and monetary authorities is found in the use of interest rate targeting. Abdurrahman, et al., (2016) investigated the empirically two-way correlation of the effectiveness of financial policy and macroeconomic variables by using the structural-VAR model and non-recursive detection of small open economy. The essential point of this paper is to explore the monetary policy shocks in the occurrence of external variables. Further it is revealed in this study that in the case of higher inflation, the efficiency of the monetary channels shows a good performance in the long run. Furthermore, in monetary policy the interest rate plays a central role in maintaining low inflation. Although tightening the monetary policy has a positive impact on high inflation, it creates fluctuations in prices in the short term. Finally, the inclusion of external variables in the model indicates that the effects on domestic financial variables in the model reduced.

Ghafoor (2018) investigated the impact of monetary policy behaviour on economic growth of Pakistan. He applied multiple regressions and correlation techniques for analysis the time series data and explained the relationship among the selected variables. He found that, there is a long run relationship between monetary policy and the macroeconomics channels. Monetary policy has significant effect on inflation rate, money supply, employment, and economic growth. Therefore, the monetary policy leads to improve economic growth and a positive impact on economic growth. He suggested that should give a ultimate authority to the policy makers and central bank, but at same time, it must have coordination with fiscal authority.

This review of literature suggests that the monetary policy play a principle role for industrial growth through its direct impact on the investment. It also influences the balance of payments and exchange rate policy. Based on this review we have used a model based on Waliullah et al (2010), Dingela and Khobai (2017) in the next section for empirical analysis.

\section{Model and Methodology}

\subsection{Theoretical Model}

In line with the objectives, we can now define the framework of this study. To estimate the macroeconomic policy model for Industrial Sector Growth, the ARDL model is being broadly used in monetary policy channels to find the short run and long run relationships of variables. Here, we have used five variables similar to the model used by Waliullah et al (2010), Dingela and Khobai (2017) and Ezeaku et al (2018). The simple linear regression equations for industrial sector as follows:

$\operatorname{Ln}\left(\mathrm{Y}_{\mathrm{t}}\right)=\beta_{0}+\beta_{1} \operatorname{Ln}\left(\mathrm{CPI}_{\mathrm{t}}\right)+\beta_{2} \operatorname{Ln}\left(\mathrm{M}_{\mathrm{t}}\right)+\beta_{3} \mathrm{MMR}_{\mathrm{t}}+\beta_{4} \operatorname{Ln}\left(\mathrm{NEER}_{\mathrm{t}}\right)+\varepsilon_{t}$

Where $Y_{\mathrm{t}}$ is the industrial/manufacture production at given time period, M2 is the money supply, CPI is the consumer 
price index, MMR is the money market and last variables is the Nominal Effective Exchange Rate (NEER). All these variables are set in logarithmic form, except the Money Market Rate. In the recent literature of financial econometrics, it has been focused on integration of the model into the short run dynamic adjustment process. The speed of adjustment from short-run to long-run equilibrium is necessary for the ARDL approach. In this principle, we prepared ECM by modifying the equation (1) as follows:

$$
\begin{aligned}
\Delta \operatorname{Ln}\left(\mathrm{Y}_{\mathrm{t}-1}\right)= & \beta_{0}+\sum_{i=1}^{n I} \beta_{1} \Delta \operatorname{Ln}\left(\mathrm{Y}_{\mathrm{t}-1}\right)+\sum_{i=0}^{n I I} \beta_{2} \Delta \operatorname{Ln}\left(\mathrm{CPI}_{\mathrm{t}-1}\right)+\sum_{i=0}^{n I I I} \beta_{3} \Delta \operatorname{Ln}\left(\mathrm{M}_{\mathrm{t}-1}\right) \\
& +\sum_{i=0}^{n I V} \beta_{4} \Delta \mathrm{MMR}_{\mathrm{t}-1}+\sum_{i=0}^{n V} \beta_{5} \Delta \operatorname{Ln}\left(\mathrm{NEER}_{\mathrm{t}-1}\right)+\mathrm{S}_{\mathrm{t}-\mathrm{i}}+\varepsilon_{t}
\end{aligned}
$$

The equation 2 represents the short run dynamics of the model, where the symbol ' $S$ ' shows the speed of adjustment factor in terms of Error Correction Model (ECM) derived from the baseline equation 1. The $B_{0}$ represents the constant term in the each equations. $B_{1}$ to $B_{6}$ is the coefficients, $\varepsilon_{t}$ is the error term and $n$ is the number of lag length of $i$. While $\Delta$ symbol is indicate for change.

According to the past empirical analysis, if we have a mix order of variables (i.e. integrated order at I (0) and I (1)), then we will go for ARDL or Bound test for the co-integration analysis. Therefore, we will develop the ARDL or Bound test to find the relationships of variables in system which integrates into one step function, suggested by Engel and Granger (1987). For this purpose we substitutes $S_{t-1}$ in Equation 2 for lagged variables of the dependent variable and the independent variables. The ARDL model is therefore particular in Equation 3.

$$
\begin{array}{r}
\operatorname{Ln}\left(\mathrm{Y}_{\mathrm{t}-1}\right)=\alpha_{0}+\beta_{1} \operatorname{Ln}\left(\mathrm{Y}_{\mathrm{t}-1}\right)+\beta_{2} \operatorname{Ln}\left(\mathrm{CPI}_{\mathrm{t}-1}\right)+\beta_{3} \operatorname{Ln}\left(\mathrm{M}_{\mathrm{t}-1}\right)+\beta_{4} \mathrm{MMR}_{\mathrm{t}-1}+\beta_{5} \operatorname{Ln}\left(\mathrm{NEER}_{\mathrm{t}-1}\right) \\
+\sum_{i=1}^{n} \Delta \operatorname{Ln}\left(\mathrm{Y}_{\mathrm{t}-\mathrm{i}}\right)+\sum_{j=0}^{n} \Delta \operatorname{Ln}\left(\mathrm{CPI}_{\mathrm{t}-\mathrm{j}}\right)+\sum_{k=0}^{n} \Delta \operatorname{Ln}\left(\mathrm{M}_{\mathrm{t}-\mathrm{k}}\right) \\
+\sum_{l=0}^{n I V} \Delta \mathrm{MMR}_{t-1}+\sum_{m=0}^{n} \Delta \operatorname{Ln}\left(\mathrm{NEER}_{\mathrm{t}-\mathrm{m}}\right)+\varepsilon_{t}
\end{array}
$$

Here $i, j, k, l$, and $m$ represent the lags of all the endogenous variables of the model. The main assumption in this model is that the long run coefficients of the model are equal to zero. However, the bound pattern for the short run dynamics is estimated based on the Error Correction Model (ECM) as symbolize in our equation (2).

\subsection{Data and Variables Description}

The monthly data of variables from 2000M01 to 2019M02 have been collected from different database and the sample consisted of 230 observations in for Pakistan.

Table No. 1: Description of Variables:

\begin{tabular}{|l|l|c|}
\hline \multicolumn{1}{|c|}{ Variables } & \multicolumn{1}{c|}{ Description } & Symbols \\
\hline Industrial/Manufacturing Productivity Index & At constant prices 2010 & Y \\
\hline Consumer Price Index (CPI) & CPI at constant prices 2010 & CPI \\
\hline Nominal Effective Exchange Rate & Rupees per Dollar & NEER \\
\hline Money Supply & In million rupees (seasonally adjusted) & M2 \\
\hline Interest Rate/ Money Market Rate & Monthly cost of money & MMR \\
\hline
\end{tabular}

In the Data, we include Manufacturing/industrial productivity index (Y) at constant prices 2010. Consumer Price Index (CPI) at 2010 base is used to measure inflation rate. The Nominal effective exchange rate (NEER) is indicating in rupees per dollar at 2010 base and proxies the effects of currency rate with other trading partners. Money Supply is in million rupees by SBP to investigate the growth rate of currency in selected period. MMR is the monthly interest rate settled at money market.

\section{Empirical Analysis}

\subsection{Results from Unit Root Test}


Table (2) shows the mean reverting property test for all variables set in logarithmic form except the domestic Money market Rate (MMR). The test results indicate that all variables are stationary at $1^{\text {st }}$ difference except $M M R$, i.e., I(0). Thus the results dragged us towards ARDL approach, because data has mixed order. Actually, we are interested in the study of dynamic responses of the variables in short run and long run pattern. So we pursue the ARDL approach to investigate the long run and short run relationships among variables.

Table No. 2 Unit Root Test Result (ADF)

\begin{tabular}{|c|c|c|c|c|c|}
\hline Variables & Coefficient & $\begin{array}{c}\text { Critical Value at } \\
\mathbf{5 \%}\end{array}$ & Test Statistic & $\begin{array}{c}\text { Intercept/ } \\
\text { Trend }\end{array}$ & Results \\
\hline LnIMPI & -0.91 & -3.4294 & -13.49 & I/T & $1^{\text {st }}$ Difference \\
\hline LnCPI & -0.48 & -2.5750 & -7.21 & None & $1^{\text {st }}$ Difference \\
\hline LnNEER & -0.59 & -1.9422 & -10.09 & I/T & $1^{\text {st } \text { Difference }}$ \\
\hline LnM2 & -1.21 & -2.8739 & -17.87 & I/T & $1^{\text {st } \text { Difference }}$ \\
\hline MMR & -1.09 & -2.8374 & -4.15 & I/T & Level I $(0)$ \\
\hline
\end{tabular}

\subsection{Lags Order choice Criteria}

There are several methods to select the lag length of an ARDL model. In this study, we have used three powerful criteria to select the lag length criteria; namely AIC, SC, and HQ. All the methods are listed in table 3, which provides the mostly selected lag lengths under special information criterion. All these criteria present a different lag length. In this case we have to rely on the SC which is significant at lag $(1,1)$ because at this lag length we would face less loss to degree of freedom. Thus our ARDL model (equation 3 above) is estimated at lag $(1,1)$.

Table No. 3: Lags Order of Selection criterion.

\begin{tabular}{|c|c|c|c|}
\hline Lags & A.I.C & S.C & H.Q \\
\hline 0 & 0.69 & 0.76289 & 0.807 \\
\hline 1 & -17.58 & $-18.133^{*}$ & $-17.819^{*}$ \\
\hline 2 & $-18.21^{*}$ & -17.052 & -16.581 \\
\hline 3 & -18.02 & -17.069 & -17.081 \\
\hline 4 & -17.993 & -14.173 & -17.003 \\
\hline $\begin{array}{c}\text { Note: The subscript * indicates the lags order selected by criterion. AIC = Akaike Information } \\
\text { Criterion, SC=Schwarz Information Criterion, FPE stands for Final Prediction Error and HQ } \\
\text { is Hannan-Quinn information criterion. }\end{array}$ \\
\hline
\end{tabular}

\subsection{Descriptive Statistics}

Statistical analysis is important for time-series analysis and provides information about central tendency (Mean, Median, and Mode) and measure of dispersion (Range, Variance and Standard Deviation) and measure of normality (Kurtosis and Skewness). Before embarking on the analysis of the variables in the model, we must check whether our data are normally distributed or not. The descriptive statistics results are shown in the table 4, exhibit that the Y and MMR are normally distributed because the difference between the values of mean and median are minimal. Throughout, the literature of monetary policy uses the difference between the values of mean and median for checking the normality of the variables. CPI, M2 and NEER are not normally distributed, because the difference between the values of mean and median is higher. So in time-series a handy solution is to transform the variables into log-form for normality issue.

Table No. 4: Descriptive Statistics

\begin{tabular}{|c|c|c|c|c|c|}
\hline & Y & CPI & NEER & M2 & MMR \\
\hline Mean & 93.70319 & 89.57697 & 128.225 & 5720018 & 8.22909 \\
\hline Median & 97.945 & 81.52735 & 113.162 & 4644518 & 8.775 \\
\hline Maximum & 163.97 & 162.724 & 211.883 & 15931393 & 20.03 \\
\hline
\end{tabular}




\begin{tabular}{|c|c|c|c|c|c|}
\hline Minimum & 41.89 & 40.601 & 79.0466 & 1221780 & 0.74 \\
\hline Std. Dev. & 27.00944 & 42.05261 & 38.4414 & 4075962 & 3.22070 \\
\hline Skewness & -0.170055 & 0.34319 & 0.34107 & 0.826897 & -0.11378 \\
\hline Kurtosis & 2.511192 & 1.529145 & 1.64634 & 2.62 & 3.10372 \\
\hline \multicolumn{7}{|c|}{ The test of Normality, Jarque-Bera results of ARDL. } \\
\hline Jarque-Bera & 3.427879 & 25.46714 & 22.2112 & 27.83453 & 0.60464 \\
\hline Probability & 0.180155 & 0.000003 & 0.000015 & 0.000001 & 0.73910 \\
\hline
\end{tabular}

\subsection{Bounds test for Cointegration}

To finds the long run relationship among the variables of different order $\mathrm{f}$ integration, there is a need to rely on Pessaran et. al. (2001) test, so-called Bounds test. The short run dynamic behaviour and relationship among economic variables are found through an underlying Error Correction Model and F-Statistics.

\subsubsection{Bounds Test for Existence of Long Run Relationshi:}

The value of F-statistics from estimated equations $(\mathrm{F}=8.40)$ is greater than the lower and upper critical Bounds at $5 \%$ and $10 \%$ significance level respectively as shown in the table 4 . It indicates that there is an existence of long run relationships between variables at the given significance level. The bounds test also indicates that, all variables have an equilibrium condition that keeps them in the long run.

Table No. 5: Existence for long run relationship between Monetary Channels and IPI

\begin{tabular}{|c|c|c|}
\hline Test statistic (Y, CPI, M2, MMR, NEER) & Value \\
\hline F-Statistics & 8.4007 & 4 \\
\hline \multicolumn{2}{|c|}{ Critical Value Bounds } \\
\hline Significance & I0 Bounds & II Bounds \\
\hline $10 \%$ & 2.2 & 3.09 \\
\hline $\mathbf{5 \%}$ & $\mathbf{2 . 5 6}$ & $\mathbf{3 . 4 9}$ \\
\hline \multicolumn{2}{|c|}{ Null Hypothesis: No long-run relationships exist at (5\%) } \\
\hline
\end{tabular}

\subsubsection{Co-integration Results (Short Run Estimates)}

Table 6 describes the Co-integrated short run results for selected variables such as LnCPI, MMR, LnM2 and LnNEER. This indicates that the coefficients of prices and interest rate are negative and statistically significant. The short run results also show that the error correction term is negative (as predicted) and statistically significant. This suggests that there is a process of about three periods to correct towards the long run stable path. The coefficients of money supply and exchange rate are statistically equal to zero referring to no short run impact of these variables on the output. The equilibrium in the system is corrected at the adjustment rate of $30.3 \%$ in each period.

Table No. 6: Estimated Short run Error Correction Model [ARDL: 1, 1, 0, 1, and 0]

\begin{tabular}{|c|c|c|c|c|}
\hline \multicolumn{5}{|c|}{ Dependent Variable: LnY } \\
\hline Variables & Coefficients & Std-Error & T-Statistic & Probability \\
\hline$\Delta$ (LNCPI) & -2.51107 & 0.57961 & -4.332331 & 0.0000 \\
\hline$\Delta$ (LNM2) & -0.22300 & 0.35573 & -0.626872 & 0.5314 \\
\hline$\Delta$ (MMR) & -0.00683 & 0.00314 & -2.175385 & 0.0307 \\
\hline$\Delta$ (LNNEER) & 0.05509 & 0.33914 & 0.162467 & 0.8711 \\
\hline Ect 1 (LN & -0.30302 & 0.03971 & -7.630796 & 0.0000 \\
\hline
\end{tabular}

Note: * Level of Significant at 5 percent. 


\subsubsection{Long Run Estimates}

Table 7 shows the long run estimated coefficients and suggests that, the lnCPI and lnNEER has a negative and significant impact on industrial production; means in the long run the output is highly sensitive to prices and responses negatively. The depreciation (an increase in exchange rate in this case) reduces the output, by making exports cheaper and exports costlier. In Pakistan there is huge current account deficit which confirms that the long run impact of depreciation is negative on output. Moreover, Pakistan's industrial sector produces primary and semimanufacturing goods which do not generate high revenues in international market

Table No. 7: ARDL Coefficients for Long run [1, 1, 0, 1, 0,]

\begin{tabular}{|c|c|c|c|c|}
\hline \multicolumn{5}{|c|}{ Dependent Variable: LnY } \\
\hline Variables & Coefficients & Std-Error & T-Statistic & Probability \\
\hline LNCPI & -1.847283 & 0.32772 & -5.63669 & 0.0000 \\
\hline LNM2 & 1.232038 & 0.13812 & 8.92007 & 0.0000 \\
\hline MMR & 0.01507 & 0.00863 & 1.74623 & 0.0906 \\
\hline LNNEER & -0.789958 & 0.36438 & -2.16790 & 0.0312 \\
\hline C & -2.514989 & 2.73302 & -0.92022 & 0.3585 \\
\hline
\end{tabular}

Note: * Level of Significant at 5 percent.

Thus depreciation which is sometimes an encouraging factors for exporters does not draw the attention of the producers. The money supply increases the output level and helps the produces to get easy loans. So, an expansionary monetary policy can play a role to boost the industrial sector. Although the sign of MMR is against the theoretical logic, however, this channel of monetary policy has statistically insignificant relationship at 5\% level of significance and has very small numerical value.

\subsection{Diagnostic Tests}

The diagnostic test results are presented in the table 8. Jarque Bera test shows that there is normality is restored in the series of the model after log transformation. Similarly the Breusch-Pagan-Godfrey (B-P-G) and LM tests confirms the absence of serial correlation. Both these test also confirm through F-statistics that there is homoscadasticity in the residuals of the estimated model. This problem has been solved by including the white heteroscedasticity-consistent standard errors and covariance in ARDL model.

Table No. 8: Diagnostic Tests for ARDL Model

\begin{tabular}{|l|c|c|c|}
\hline \multicolumn{3}{|c|}{ Results: } \\
\hline Tests: & Jarque Bera & B-P-G & LM Test \\
\hline Normality: & 4.3822 & & 2.0267 \\
\hline Obs $*$ R-squared Value: & & 29.016 & 1.9649 \\
\hline F-Statistic: & & 4.5764 & 0.1546 \\
\hline Prob Value: & 0.1117 & 0.0001 & \\
\hline
\end{tabular}

\subsubsection{CUSUM Tests for Structural Break}

Figure 1 shows that, the stability of the long run coefficients by using the Cumulative Sum of Recursive Residuals (CUSUM) test. Our results confirmed that the tested line falls between the critical lines at 5\% level of significance. Therefore, it can be acceptable that our selected (ARDL) model is stable and there is no structural break in model.

Figure 1: Cumulative Sum of Recursive Residuals 


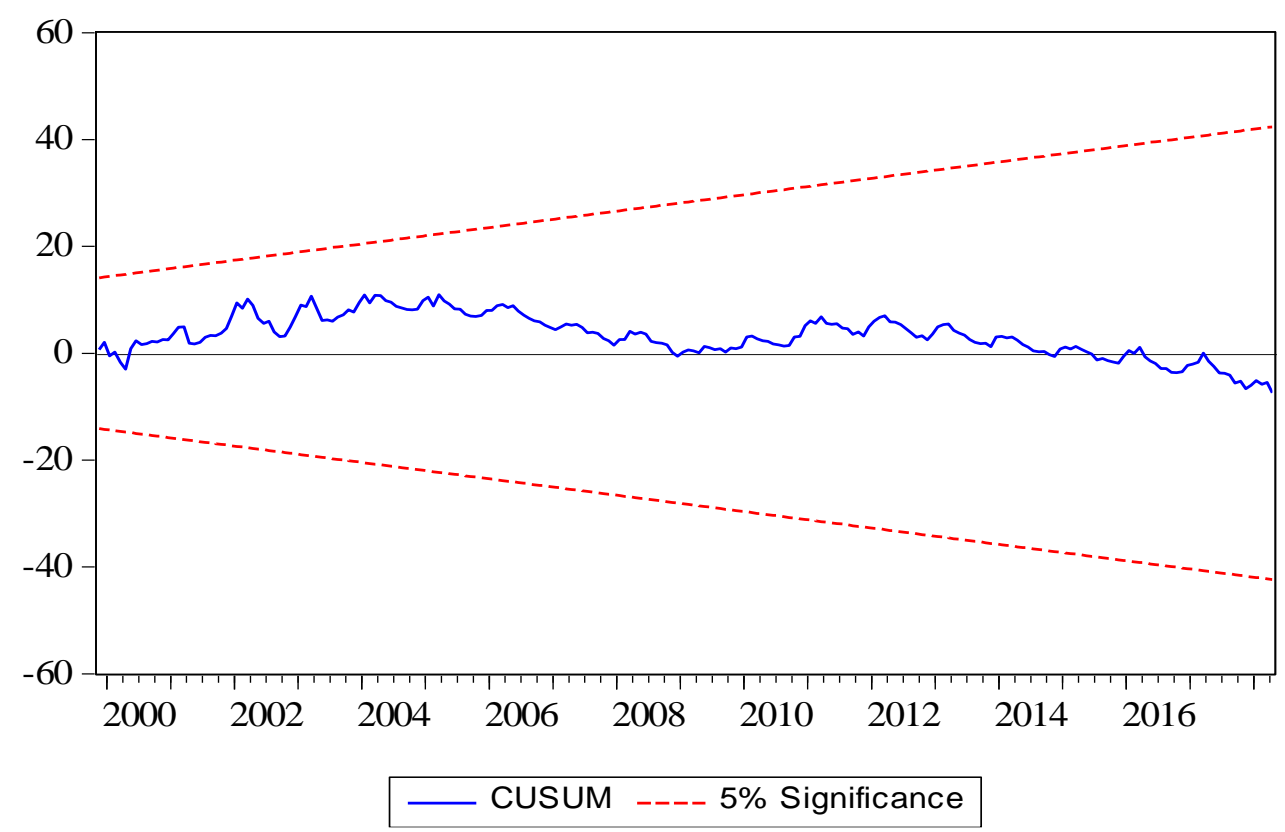

\section{Conclusion}

This study has examined the impact of monetary policy variables in the presence of exchange rate and prices on the industrial production by employing monthly data from 1999M01 to 2018M04. The study aim was to explore whether the monetary policy channels are attractive for industrial productivity or not. The empirical findings proved that, the industrial manufacture product is co-integrated with consumer price index, money supply, money market rate and nominal effective exchange rate particularly in long run. The equilibrium in the system is corrected at the adjustment rate of $30 \%$. The role of policy variables such as money market rate and money supply confirm the monetary policy channel. For industrial production we found that the money supply channel has shown more robust effects than the interest rate channel. Prices have a damaging effect on output in every period of our study. These results are consistent with Forni and Ganbetti (2008) and Rabi and Waliullah (2011)

Our results imply that the expansionary monetary policy through money supply channel is more effective in the long run for industrial productivity and can further boost the economic growth. However, for impact period the interest rate channel is more effective; this may be because in short run the objective of the monetary policy is generally to control inflation instead of growth. Based on our conclusions, it can also be implied that the increase in prices should be tackled through monetary policy to help boost the output in long run.

\section{References}

Aleem, A. (2010). Transmission mechanism of monetary policy in India. Journal of Asian Economics, 21(2), 186197.

Bernanke, B. S., \& Mihov, I. (1998). Measuring monetary policy. The quarterly journal of economics, 113(3), 869902.

Dingela, S., \& Khobai, H. (2017). Dynamic Impact of Money Supply on Economic Growth in South Africa. An ARDL Approach.

Enders, W. (2008). Applied econometric time series. John Wiley \& Sons.

Ezeaku, H. C., Ibe, I. G., Ugwuanyi, U. B., Modebe, N. J., \& Agbaeze, E. K. (2018). Monetary Policy Transmission and Industrial Sector Growth: Empirical Evidence From Nigeria. SAGE Open, 8(2), 2158244018769369.

Forni, M., \& Gambetti, L. (2010). The dynamic effects of monetary policy: A structural factor model approach. Journal of Monetary Economics, 57(2), 203-216.

Hanif, M. N. (2014). Monetary policy experience of Pakistan.

Kripfganz, S., \& Schneider, D. C. (2018, September). ardl: Estimating autoregressive distributed lag and equilibrium correction models. In Proceedings of the 2018 London Stata Conference. 
Mustafa, K., Ahmed, R., \& Siddiqui, A. A. (2013). Money supply and equity price movements in Pakistan. European Journal of Business and Management, 5(5).

Qayyum, A. (2008). Does Monetary Policy Play Effective Role in Controlling Inflation in Pakistan. University Library of Munich, Germany.

Shobande, O. A. (2019). Monetary Policy Spillovers Through Industrial Growth in Nigeria: A Time Series Analysis. Economics and Business, 33(1), 94-110.

Uhlig, H. (2005). What are the effects of monetary policy on output? Results from an agnostic identification procedure. Journal of Monetary Economics, 52(2), 381-419.

Vinayagathasan, T. (2013). Monetary policy and the real economy: A Structural VAR Approach for Sri Lanka. National Graduate Institute for Policy Studies, 13(13), 1-31.

Waliullah, W., \& Rabbi, F. (2011). Effectiveness Of Monetary Policy In Pakistan: Empirical Evidences Based On Bound test Approach. International Journal of Business and Social Science, 2(1). 